AperTO - Archivio Istituzionale Open Access dell'Università di Torino

Environmental and innovation policies for the evolution of green technologies: a survey and a test

This is a pre print version of the following article:

Original Citation:

Availability:

This version is available http://hdl.handle.net/2318/1528424

since 2016-05-30T12:07:09Z

Published version:

DOI:10.1007/s40821-015-0027-z

Terms of use:

Open Access

Anyone can freely access the full text of works made available as "Open Access". Works made available under a Creative Commons license can be used according to the terms and conditions of said license. Use of all other works requires consent of the right holder (author or publisher) if not exempted from copyright protection by the applicable law. 


\section{Environmental and Innovation policies for the evolution of green technologies: a survey and a test}

\section{Introduction}

Assessing climate change related challenges is at the core of the current European environmental policy agenda.

On the one hand, the Europe 2020 strategy (EC 2010a, 2010b) set the following goals for European Countries: i) to achieve a $20 \%$ reduction in greenhouse gas (GHG) emissions as compared to 1990 levels; a 20\% reduction in the share of renewable energy sources used in final energy consumption; iii) a $20 \%$ reduction of final energy consumption compared to business as usual scenario to be achieved through improved energy efficiency.

On the other hand, with the launch of the policy framework for climate and energy for 2030 it has become even clearer that Member States are expected to further improve their efforts towards a low-carbon economy. ETS $^{1}$ and non-ETS sectors are indeed subject to the new target of reducing greenhouse gases emissions (GHG) of 40\% with respect to 1990 by 2030 (EC, 2014).

The actual achievement of these targets depends not only on the selection process of the available policy instruments (which will be discussed in Section 3) but also on the effects that policies may have on competitiveness, either at a micro, meso or macro perspective.

Since the formulation of the Porter Hypothesis (PH) (Porter \& Van der Linde, 1995), much emphasis has been given to the potential competitive and productive gains (rather than losses) that might be deriving from the adoption of stricter environmental regulation. Jaffe and Palmer (1997) propose to identify three different versions of this hypothesis. The 'weak' version postulates that environmental regulations stimulate innovation productivity. The 'strong' version argues that regulation-driven "innovation offsets" might exceed the costs of compliance, which might result in net productivity gains. Lastly the 'narrow' version posits that well-designed regulations give firms greater incentives to innovate and thus will have less adverse impact on productivity.

Understanding how environmental policies can avoid harming growth, either in strong, weak or narrow terms, is indeed a crucial issue in designing policies.

Strong empirical research effort has been devoted to the analysis of the effects of environmental policies both on innovative activities (mainly weak version of $\mathrm{PH}$ ) and on competitiveness (narrow or strong version of $\mathrm{PH}$ ).

With respect to the first group, the literature mainly recognizes that regulation strongly induces technological change (Brunnermeier \& Cohen, 2003; Costantini \& Mazzanti, 2012; Horbach et

\footnotetext{
${ }^{1}$ ETS stands for European Trading System, working on a 'cap and trade' principle. For more information on this policy scheme the reader can look at the European Union website http://ec.europa.eu/clima/policies/ets/index_en.htm.
} 
al.2012; Jaffe \& Palmer, 1997; Johnstone et al. 2010a; 2010b; 2012; Lanjouw \& Mody, 1996; Rennings \& Rexhäuser, 2011; Ghisetti and Quatraro, 2013). These empirical evidences in other terms support the hypothesis that properly designed policies foster firms' decisions to improve their products or production processes introducing environmental innovations.

With respect to the second group, the effects of environmental policies on productivity might be more complex than policies on innovation, as regulation may improve productivity in some specific activities in the short run but at the same time might engender counter indirect effects.

Berman and Bui (2001) found that air pollution regulation in the oil refining industry determined significant productivity gains. On the contrary, Gray and Shadbegian (1998) in analyzing the pulp and paper industry found that pollution abatement investments "crowded out" more productive investment, while Greenstone (2001) found a negative productivity impact engendered by air pollution regulation.

In principle, at the aggregate level it might be that regulation eliminates less efficient firms thus raising productivity but it might also be that it acts as an entry cost that, in reducing competition, lowers productivity levels. All in all "empirical research on the productivity effects of environmental policies is largely inconclusive. Results are usually very context-specific and hence of little use for policy makers deciding on which tools to choose to tackle a particular environmental issue" (Kozluk and Zipperer, 2013:21). Overall "a priori, it is however unclear whether these indirect effects are negative or positive, or whether they are large enough to outweigh the drag of the direct effect" (Kozluk and Zipperer, 2013:9). Although early studies have found a negative link between regulation and productivity (Palmer et al., 1995), Ambec et al. (2013) in a more recent review explain the conflicting previous results in terms of a set of factors such as the environmental problem addressed by regulation, the sector and market conditions, the methodology followed and firms specificities in terms of management.

In parallel, a further aspect that deserves consideration when discussing about environmental policies is their possible side effect on non-regulated systems. The increase in environmental policies stringency can indeed generate "pollution havens". According to the pollution haven hypothesis, differences in policy stringency among countries can encourage those exposed to less stringent regulation to gain competitive advantages in the production and export of "dirty" products. On the contrary, those facing stricter regulations will be tempted to relocate in other countries their production, in order to escape regulation. As a result, the offshoring of polluting production processes in countries with less stringent regulation may even result in greater global pollution, as environmental efficiency (i.e. pollution per unit of output) in these countries is expected to be systematically worse than that observed in more regulated countries.

Although evidence on this hypothesis is still inconclusive (Brunnermeier \& Levinson, 2004; Cave \& Blomquist, 2008), as Cave and Blomquists's (2008) empirical analysis points out, there is evidence of a greater amount of imported energy-intensive goods by EU countries from other countries with weaker regulation in correspondence of increasing stringency of EU environmental policies.

The objective of this paper is to discuss the different policy instruments that can be relevant in shaping innovation in environmental friendly technologies by providing a taxonomy of different 
classes of instruments both in the environmental and innovation domains. The joint analysis of these two sets of policies appears to be relevant as previous literature has showed that contrasting effects between environmental goals and competitiveness can be mitigated when environmental policies are positively integrated with innovation and technology policies. When this happens the inducement effects of environmental policies on the generation of green innovations can be greater as adequate technological capabilities are available and it is easier to catch new market and technological opportunities (Costantini and Crespi, 2008; Horbach et al., 2012). An econometric test on the relevance of the reviewed policies in shaping different types of eco-innovations is provided in Appendix.

The reminder of the paper is organized as it follows. Section 2 presents a description of environmental policies by type of policy instruments. Section 3 discusses the intertwining between innovation and environmental policies while 4 provides a synthesis and elaborate a framework to integrated innovation-oriented environmental policy.

\section{Environmental policies}

Environmental policies are built through the adoption of one or possibly a combination of a set of policy instruments. According to their nature, those might be classified as it follows (OECD, 2010):

\section{Market/Incentive-based instruments}

2. Command and Control regulation instruments

3. Voluntary (also called negotiated) agreements

4. Information / Education-based instruments

The market-based and command and control regulatory instruments "may be thought of as 'hard' instruments, because they impose explicit obligations, whereas voluntary and information-based instruments may be thought of as 'soft' instruments, because they rely more on or seek to stimulate discretionary activities" (Ekins, 2010: 282).

This section discusses these groups of policy instruments, combining the description of the instruments with some examples of effective policies at stake and their strengths and weaknesses in order to provide (into Section 4) some prescriptions on how to choose among them.

\section{Market or Incentive Based Instruments}

The first set of existing instruments aims at indirectly reducing environmental pressure by introducing market incentives that correct for externalities and balance the private with the social prices. Such instruments span from emissions trading, environmental taxes and charges, depositrefund systems, subsidies and compensation mechanisms and green purchasing (EEA, 2005).

These instruments may encourage firms towards pollution control, as it becomes their own interest and allow to collectively meeting policy goals (Stavins, 2003).

Emission trading schemes may mainly consist in cap-and-trade or credit systems. Cap-and-trade systems impose an upper threshold for selected pollutants (cap) and then the permits to pollute are allocated and traded (trade) in order to reach a cost-effective way to reduce emissions. The 
European Trading Scheme (EU ETS), established under the Directive 2003/87/EC, is a concrete example of cap-and-trade system and the largest available in the world, which has been set as the cornerstone of EU's strategy for addressing climate change. EU ETS, launched on January 2005, set a legally binding cap on $\mathrm{CO}_{2}$ emissions and equivalents (nitrous oxide $\mathrm{N}_{2} \mathrm{O}$ ) and per-fluorocarbons (PFCs) that covers power and heat generating plants, energy intensive industry sectors (including refineries, steel works and production of iron, aluminum, metals, cement, lime, glass, ceramics, pulp, paper, cardboard, acids and bulk organic chemicals) and aviation. The European cap was concretely translated into country caps (National allocation plans) and a market of allowances has been built, that gives those who hold the permit the right to emit one ton of carbon dioxide $\left(\mathrm{CO}_{2}\right)$ or equivalent gases per permit. The sectoral distribution of national caps has been established in a decentralized way at each country level.

In a first phase (2005-2007), the testing phase, allowances were distributed free of charge following the principle of historical emissions (grandfathering), or of benchmarking based on projected emissions for new entrants. The choice of allocation free of charge was to reduce resistance from industry by offsetting part of the adjustment costs (Zetterberg, 2014). However, this ex ante free allocation has the drawback of reducing the consensus around the policy if this is perceived as unfair because it gives dirty emitters more allowances than to firms who already moved to cleaner production techniques. A penalty for non-compliance to the cap was set as well as national registers to monitor allowances. In a second phase (2008-2012) allowances were still distributed for free, but the penalty has been increased and the amount of emissions covered by the cap was reduced by $6.5 \%$. The last phase substituted free allowances with an auctioning process and moved the allocation from national governments to the central authority. For sectors that are not covered by the EU ETS, each member state has to individually design measure that lead to a $10 \%$ reduction in emission by 2020, compared to 2005 levels. Although the EU ETS has been seen as possible bench for a global cap and trade system, its application presented a lot of problems spanning from the over-allocation of allowances in the first phase and transparency problems (e.g. Vlachou, 2014) to the apparently neutral effects of EU ETS on innovative activities (Borghesi et al. 2012; Calel \& Dechezleprêtre, 2014). EU ETS effects on $\mathrm{CO}_{2}$ reduction are instead less controversial, as previous empirical literature outlined its positive environmental effects (Martin et al. 2014a; 2014b). EC proposed indeed a strong revision of the Scheme for its third phase 2013-2020 (EC 2008).

Credit systems set a minimum level on the emission performance instead of imposing a quota on emissions, and participants receive credits from the emission reductions they achieved with respect to the selected baseline. An example of this system is the Clean Development Mechanism (CDM) of the Kyoto Protocol aimed at favoring technology transfer that gives industrialized countries to develop or finance projects that reduce greenhouse gas emissions in other countries to obtain emission reduction credits. Furthermore, CDM gives technical and financial support for the diffusion of green technology towards countries who have not accepted the emission reduction targets (Dechezleprêtre et al., 2008).

Environmental taxes and charges are ways to internalize in the producers those external costs that are spread over the society in terms of environmental damage, for instance by imposing a tax on pollutant activities. A Carbon tax is probably the most common type of environmental tax. Regulation sets a price for $\mathrm{CO} 2$ (or $\mathrm{CO} 2$ equivalent) emissions which the polluters are required to pay for its emissions. 
Alternatively the tax can be set on inputs of the production process, for instance on fuels, water usage or pesticides or on outputs, for instance on air tickets. De Serres et al (2010) provide a synthesis of the existing taxes or charges by environmental domains for separately considered OECD countries.

Not only $\mathrm{CO}_{2}$ emissions can be taxed, but other emissions as well: $\mathrm{SO}_{2}$ and $\mathrm{NO}_{\mathrm{x}}$ are under an emission tax in several countries e.g. Norway, Sweden, Finland, the Netherlands, France, Slovenia, although with a quite high variation of tax rates (Requate, 2005).

A recent EEA study (EEA, 2014) shows that the debate on environmental taxes has not lead to a widespread application of such an instrument. During 1995-2012, EU-27 environmental taxes as a percentage of GDP fell indeed from $2.8 \%$ in 1999 to $2.3 \%$ in 2008, while environmental taxes as a percentage of total tax revenues from $6.9 \%$ to $5.9 \%$ (EEA, 2014). Those taxes are mainly depending on energy taxes, which contribute to the largest share.

Morley (2012) empirically tested at EU wide scale the effectiveness of environmental taxation on both pollution and energy consumption. His findings are of an effective negative effect of regulation on pollution, which decreases because of the introduction of environmental taxes, while limited effect is found for the use of resources, in particular energy consumption. This lead the author to conclude that the overall impact depends also on the structure of other tax levels.

The potential positive side effect of environmental taxes deserves consideration for their positive role for fiscal consolidation, which makes them less detrimental than other taxes for growth (EC, 2012; 2013). Even leaving aside the concerns about the negative effects of environmental taxation on competitiveness, carbon pricing schemes did not prove to engender any statistical significant impact on electricity retail prices (EC, 2014). Moreover, revenues from the tax can be reinvested by the government in eco-innovation, increasing both patenting and thus technology efficiency employment (EEA, 2011) and increased efficiency of technology. In a study by De Vries and Medhi (2008) it has been found that an increase in fuel prices by 0.1 US\$ per liter created $14 \%$ increase in patenting activity.

However, for environmental taxes or cap-and-trade systems to be effective, the harmonization of environmental policies across countries is required. In the absence of such a harmonization, there exist a concrete risk of relocation of production toward countries having adopted less strict regulation, also known as "carbon leakage". The industrial relocation not only would weaken the environmental effectiveness of a policy, but would also result in deep costs for the society in terms of job losses. As a consequence to that, energy-intensive firms usually find grants or exemptions in the presence of a carbon tax, even though this does not make the polluter-pays principle effective (Martin et al., 2014).

Instead of adding a tax on pollution, the policy maker can alternatively subsidize environmentalfriendly activities, to directly encourage the reduction of negative externalities. The subsidy can mainly take the form of a grant, a tax reduction or of a soft loan ${ }^{2}$. One of the most typical examples

\footnotetext{
${ }^{2}$ Soft loans are low rate or interest-free loans provided by financial institutions to favor the acquisition of item that help the transition towards sustainability. An example of such loans is providing households with loans aimed at purchasing or installing items recommended for their home to be sustainable.
} 
is a feed-in-tariff, which is aimed at favoring the uptake for alternative energy technologies. Such tariffs are mainly used for the uptake of solar energy technologies.

Concrete examples of grants at stake range from the Flanders's Region grants to farmers to support sustainable and organic farming to Slovenia's subsidies for housing energy efficiency improvements for households. Tax reductions have been widely implemented as well, e.g. Italy's tax reduction of $0.03 €$ per $\mathrm{kWh}$ granted to users of biomass heating systems or Belgium's investment deduction for "green" R\&D investments.

The interplay between existing subsidies and environmental taxes or charges may also affect the overall environmental performance of a country. Taxes have indeed a key role in compensating for removing harmful subsidies, in the phasing out phase of environmentally harmful subsidies, as "Environmental taxation and removing environmentally harmful subsidies can unlock the economy from the unsustainable path as these policies will ensure that the real costs of resource use and environmental pollution are paid by consumers and producers.” (EEA 2014: 71)

The last instrument belonging to the category of market or incentive based systems are deposit refund systems. Those type of instruments usually act on products, such as plastic bottles, and work as a charge on the good for its disposal, which is compensated by a subsidy when it is returned to a collection point. Such a system is in place for the deposit and refund of plastic, glass and aluminum bottles in most of European countries e.g. Czech Republic, Denmark, Estonia, Finland, Germany, Hungary, Netherland, Poland and Slovenia.

\section{Command and control regulatory instruments}

Another category of hard instrument is the one labelled as "Command and control". This is composed by non-market based instruments, as prices are no longer changed, rather standard or obligations are imposed or directly or in the form non-monetary incentives of command and control.

Institutions could define a framework or performance standard or outcome to be met, or technology to be used.

Examples of concrete instruments of this field are specific performance standard on vehicle efficiency that limit the amount of emission per unit of output, or the imposition to operators to use specific abatement technologies. Further examples of this instrument are regulations that ban the use of specific products or that impose the use of certificates or registry over harmful substances. The California Zero Emission Vehicle (ZEV) Programme launched in 1990, is an example of technology forcing command and control regulation, as it imposed $10 \%$ of sold automobiles to be ZEVs by 2003.

To be considered is not only regulation's direct effect on countries adopting it but also on countries exporting to the adopters, who might be required to fit the standards that have been set, thus pushing the international diffusion of the standard. In diffusing the standard, this in turn promotes the development and diffusion of environmental technologies through two main channels. On the 
one hand exporting countries should modify their processes and products to fit the regulation. On the other hand, environmental regulation implemented in a country can push its exports towards external countries if these ground their policies based on the existing stricter market (EEA, 2014).

One significant example of the capability of an internal regulation to influence on other countries' regulation is the European Chemical Regulation, REACh, as it affects all substances that are manufactured or marketed in the EU, i.e. all chemicals that are either exported or imported to the EU, thus affecting third countries as well. Countries outside EU, in order to trade within EU are indeed required to fit the standards set by the regulation and, more precisely, to register the chemical substances used. Moreover, regulation of chemicals in countries outside EU are aligning to fit REACh (EEA, 2014).

When a standard on the use of a particular technology is set, it might however engender losses if it creates a technological lock-in or it prevent from the development of alternative and better technologies. The point is that technology forcing regulation refer to the best available technology available in the time the regulation is established, while standards should be dynamically further developed over time, in order not to force environmental innovations (EI henceforth) beyond the current technological frontier (Jänicke \& Lindemann, 2010). Technology standards they tend to "freeze the development of technologies that might otherwise result in greater levels of control" as "no financial incentive exists for businesses to exceed control targets, and the adoption of new technologies is discouraged" (Jaffe et al., 2002; 50).

For this reason, although they might have positive environmental effects, command-and-control regulations are considered as dynamically inefficient, as they do not provide enough long-term innovative incentives. The effort towards the standard indeed stops when the goal has been reached. Contrarily, the incentive in a market-based system seems to be stronger, as it does not disappear once the standard or the target has been met (Costantini et al, 2015).

\section{Voluntary agreements and information based instruments}

Softer typologies of instruments are those labelled as "Voluntary agreements" and "information based instruments".

Voluntary agreements are at stake when institutions and firms or particular industrial sectors voluntarily coordinate for the adoption of pollution reduction strategies. The nature of such agreements is broad and sanctions might be set as well for non-complying actors. The agreement can either be on a specific target to be reached, e.g. the Flanders Region's Covenant on NOx and $\mathrm{SO} 2$ emissions from electricity producers' installations, or on the implementation of a specific programs aiming at improving environmental performance, e.g. the Czech Republic's EcoLabelling system negotiated with the Ministry of the Environment.

The use of voluntary approaches is discussed as being appropriate when pollution emissions cannot be adequately monitored at the source, or when it is not clear and unambiguous which is the input or output of the production process that should be under market-based instruments. For instance, it might not be clear whether to set a tax on a specific input or output. 
It follows that the efficiency of these instruments in reducing externalities is considered insufficient, and their role is seen mostly as a complement for already existing policies "when information about the environmental impact of products or available clean goods or activities is lacking and that it is not too costly for the government (or firms) to provide such information" (de Serres et al 2010:29).

Information based instruments are instead means to improve consumer awareness on environmental impacts of goods on the market or on the available alternatives. Examples of these instruments are product certifications and labeling, such as eco-labels, which inform consumers on the environmental contents of the products in the market, or product's lifetime energy use or its greenhouse gases' emissions. Labelling and certifications may both be mandatory or voluntary in their nature.

\section{The optimal choice of environmental policies}

The choice of the set of instruments that have been previously described is not an easy task.

Since the seminal contribution of Hahn (1984), there has been indeed specific attention to the intertwining between the effectiveness of market-based environmental policies and the degree of competition. Hahn's basic intuition is that markets for permits, like those typically established by cap-and-trade, are more effective when permits markets are competitive. Actually, when a dominant firm can be devised, it will exert its power to lower down the permits' price to minimize compliance costs, insofar as it holds a net buyer position. This topic has been further analyzed and extended by Hintermann (2011), who distinguishes between the position in permits' and product markets, and emphasizes the importance of the size of the free allocation. He shows that dominant firms in product markets, which take a net buyer position, will use their dominant position in permits' markets (if any) for strategic purposes, i.e. to raise rival costs. They will therefore exploit their power to push permits' prices upwards, to threat competitors by creating barriers to enter and survive in the industry. This framework proved to be useful in analyzing the price dynamics of EU ETS. Nesta et al. (2014) instead carry out an empirical analysis on OECD countries to show that also environmental policies based on subsidies perform better when conducted in competitive markets. These works actually motivate the joint implementation of environmental and competition policies.

In a similar vein, Requate (2005) posits that under competitive conditions market based instruments usually perform better than command and control ones. An explanation to this is that environmental taxes and in general market based instruments provide longer term and more persistent incentives to innovate than others do and, moreover, flexible and thus more dynamic environmental policy instruments are seen as more effective than static ones (de Serres, et al 2011). In addition to this, the innovative effects of environmental policies are stronger when a long time horizon is set for the duration of the policy (Schmidt et al, 2012).

Johnstone, Haščič, \& Kalamova (2010) additionally propose to analyse environmental policies in terms of more specific characteristics of different instruments rather than on their market vs nonmarket nature. In particular, they focus on the following characteristics of the policy instrument: 
stringency, predictability (or certainty), flexibility, incidence, and depth of the instruments. Here follows a description for these characteristics.

- Stringency depends on how ambitious is the policy target, with respect to the baseline scenario;

- Predictability depends on how much the policy signal is consistent, foreseeable, and credible;

- Flexibility depends on the possibility given to the innovator to its best way to meet the objective set;

- Incidence is related to the question: does the policy target the externality directly, or is the point of incidence a 'proxy' for the pollutant?

- Depth is related to the question are there incentives to innovate throughout the range of potential objectives?

According to these criteria, the policy instrument is optimal when it is "stringent enough to encourage that level of innovation which results in the optimal level of emissions; sufficiently stable to give investors the necessary planning horizon to undertake risky investments in innovation; sufficiently flexible to encourage innovators to identify innovative solutions which have not yet been identified; targeted as closely as possible on the policy objective in order to avoid misallocation of innovation efforts; and, provide continuous incentives to develop abatement technologies which could (in theory) drive down emissions to zero (Johnstone at al. 2010b: 7).

So far, we outlined a set of suggestions that might help the policy maker in the choice of one instrument with respect to another, based either on the distinction between market or non-market based one or on the intrinsic nature of the instrument according to its stringency, predictability, flexibility, incidence, and depth.

Evidence outlines that it is common for countries to deploy not just one instrument rather a combination of instruments in designing environmental policies. This habit is usually labeled 'policy packages' or 'instrument mixes' or policy mixes. As all the listed typologies of environmental instruments can stimulate environmental innovations, there is a tendency to combine them all in a mixed policy, which is in principle able to correct for the predominant market failures and institutional capacities of respective countries (De Serres et al 2010; 2011).

However, this may lead to contrasting effects of policy on environmental objectives (Costantini and Crespi, 2008 and 2013; Böhringer et al., 2009; Serres et al. 2010; Borghesi et al., 2015).

Furthermore, the available evidence suggests that the proliferation of policy instruments has not even stopped the rise in CO2 concentrations in the atmosphere (Huppes, 2011). This lead some scholars to argue that more powerful systems need to be developed. A proposal in this direction is the establishment of a global carbon deposit system (Huppes, 2011), based on pricing carbon emissions from any source and any country. Wood and Jotzo's (2011) contribution goes in the direction of empirically testing the economic-environmental effects of a combination of an 
environmental tax to be added to the emission permit price. This is seen as a viable option, as the tax is in principle added to permits' price- but under certain conditions.

The selection of the most appropriate policy instrument to address a specific environmental problems, involves not only the choice of the available instruments and the design to make them effective, but also the issue as to how to combine this choice with already existing regulations.

\section{Innovation policies and the environment}

So far, the incentive to generate and adopt innovations that improve environmental performances has been mainly provided by environmental policies, which are seen more and more as key to enact inducement mechanisms. However, though environmental policies may well represent a stimulus for new research activities, innovation systems should be equipped with adequate scientific and technological knowledge in order for the economy to creatively respond to changes in policy constraints (Costantini and Crespi, 2008).

Since the seminal contributions by Nelson (1959) and Arrow (1962), a wide body of literature has acknowledged the basic fact that markets are likely to fail in the identification of the correct amount of resources to be allocated to research activities.

One solution is an Intellectual Property Rights IPR policy that enforces the functioning of the existing IPR system or, in its absence, creates a new one. This is in line with the Lindhal's approach for public policies when dealing with a problem of under-investment in innovative activities when the private benefits of such activities are lower than their social benefits. The solution proposed is that of making knowledge a "commodity", whose benefits are fully appropriable to the firm, by creating a (temporary) monopoly over the invention. This solution calls for the development of an IPR system able to protect inventions through formal protection mechanisms such as patent or trademarks.

In addition, governments have devoted significant shares of public budgets to fund not only programs aiming at fostering the generation of new scientific knowledge within research oriented institutions, but also innovative activities carried out by private firms (OECD, 2007). Despite this, the real effect of R\&D subsidies on firm's innovative activities is not clear-cut, as it is possible that public subsidies crowd-out private investment (David and Hall, 2000; David et al., 2000; Hall and van Reenen, 2000; Bloom et al., 2002).

Different motivations have been provided for potential drawbacks of public R\&D incentives. The first issue concerns asymmetric information and the consequent difficulty for policymakers and program officials to know which firms deserve to be funded (Grossman, 1991; Stiglitz and Wallsten, 2000). Other strands of literature emphasize that the opportunities relate to public support provides industries and other interest groups with an incentive to invest large resources in unproductive rent-seeking activities such as lobbying (see e.g. Tollison, 1997). Moreover, 
bureaucrats may further jeopardize the efficiency of R\&D public support by maximizing their own private utility rather than the social welfare (Link, 1977).

The allocation procedures of public subsidies do matter in this context. Two main mechanisms can be devised as far as the allocation of public subsidies to R\&D activities is concerned: i) automatic procedures typically associated with tax expenditures; ii) discretionary procedures based upon the quality assessment of research projects. The main difference between tax credits and direct grants is that the former represents a general measure that may apply to all industries and firms independently from their specific characteristics. Hence, the most important benefit of tax credit programs as compared to direct grants is that they minimize the discretionary power that public agents hold when allocating public resources.

Much literature has however criticized automatic procedures, mainly based upon tax reductions, and stressed the advantages of discretionary procedures based upon the actual screening of research projects and of direct funding of public research programs (Mazzucato, 2013). Tax credits may imply to provide support to an array of activities that often can hardly be classified as $\mathrm{R} \& \mathrm{D}$, which are likely to be performed by firms that are not actually able to properly carry out research projects and to make an effective use of the subsidies. In this respect, the risks of opportunistic behavior seem to be very relevant. Firms often classify some expenses in their balance sheets as R\&D, while they actually concern other kinds of business activities barely related to research. In parallel, firms' lobbying activities exert relevant pressure on government authorities in order to adjust the definitions of what is actually meant by "R\&D" so as to broadening the range of allowable costs (Alt et al., 2010). Moreover, according to David et al. (2000), private firms are likely to use tax credits prioritizing projects with the highest private rates of return, focusing their research efforts on projects with short term prospects. These projects are not necessarily the ones deserving public support, which should in turn be targeted to projects with the largest gap between social and private returns. Hence, even though tax credits represent a straightforward mechanism to providing public support to $\mathrm{R} \& \mathrm{D}$, and to minimize problems related to discretionary decisions from public actors, they do not seem to be the most efficient tool to spur innovation activities (Mazzucato, 2013).

Discretionary procedures based upon quality assessment of research projects to allocate $R \& D$ grants, are potentially better suited to enhance innovation investments, as they are more likely to support better research projects, and provide a framework helping identifying and supporting potential complementarities among innovative projects (Mohnen and Roller, 2005). As a matter of fact many countries do rely on discretionary selection procedures, and the empirical literature showed that despite the potential drawbacks associated with them, selective public subsidies, in general, do have a positive effect on R\&D investments (Antonelli and Crespi, 2013).

Lastly, what is called a "lead market approach" for EI needs a discussion in this framework. A lead market policy can be defined as a demand-side intervention aimed at promoting environmental technologies that can engender first mover advantages for national firms and favor the earlyadoption of EI and thus their invention and diffusion. It is characterized by the existence of price, demand, transfer, export and market structure advantages that benefit firms operating in such markets (Beise and Rennings, 2005). Innovation developed in a lead market conditions are more likely to become a dominant design and to be then globally adopted as they have been developed 
and protected in a market niche and they are then able to spread to other countries when the environmental technology is established (Quitzow et al. 2014).

The more recent innovation systems approach has further extended the range of legitimate justification and scope for public intervention in this field (Metcalfe, 1995; Georghiou and Metcalfe, 1998; Edquist, 2001). In particular, a growing body of economic literature suggested that traditional economic approaches are inappropriate for dealing with the dynamics of structural and adaptive changes in economic systems (Rammel and van der Bergh, 2003). The relevant lesson emerging from the systemic approach suggests that innovation is a complex evolutionary process distributed in a system of different agents whose behaviour and interactions are governed both by market forces and by non-market institutions (Metcalfe, 1995; Crespi and Quatraro, 2013 and 2015).

Agents' interactions and the institutions governing them determine the innovative performance of the system. The systemic framework opens up a new perspective for policy making in general and, more specifically, for the design of an appropriate policy structure to foster the dynamics of ecoinnovations. This approach highlights the interactions and interdependencies between different policies, and shows how such interactions affect the extent to which policy goals are realized.

In this context the choice of instruments and the analysis of their interactions represent crucial decisions for the formulation of policy design (Flanagan et al., 2011).

\section{Conclusions: towards an integrated innovation-oriented environmental policy}

Moving from a description of existing environmental and innovation policies, summarized into Table 1, we now discuss how to shape an integrated innovation oriented environmental policy that stimulates the evolution of environmental innovations.

Table 1: Environmental and innovation policy instruments

\begin{tabular}{|c|c|c|c|}
\hline Policy domain & Ins & nent type & Example \\
\hline $\begin{array}{l}\text { Environmental } \\
\text { Policy }\end{array}$ & 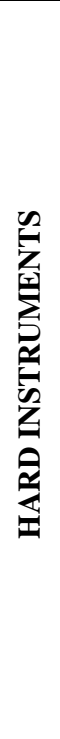 & $\begin{array}{l}\text { Market based } \\
\text { instruments }\end{array}$ & $\begin{array}{l}\text { - Emissions trading schemes } \\
\circ \text { Incentives: EU ETS } \\
\circ \text { Credits: CDM } \\
\text { - environmental taxes and charges: } \\
\circ \quad \text { on pollution: carbon tax or in general tax on } \\
\text { emissions } \\
\circ \quad \text { on inputs: tax on fuels, tax on water consumption, } \\
\text { tax on pesticides } \\
\circ \quad \text { on ouputs: tax on air tickets } \\
\text { - deposit-refund systems: } \\
\circ \quad \text { charge on disposal of a good (e.g. plastic, glass and } \\
\text { aluminum bottles) to be compensated when returned } \\
\text { to the collection point } \\
\text { subsidies and compensation mechanisms } \\
\circ \text { grant } \\
\circ \quad \text { tax reduction }\end{array}$ \\
\hline
\end{tabular}




\begin{tabular}{|c|c|c|c|}
\hline & & & $\begin{array}{r}\circ \text { soft loan } \\
\text { - } \quad \text { green purchasing }\end{array}$ \\
\hline & & $\begin{array}{l}\text { Command and } \\
\text { control } \\
\text { instruments }\end{array}$ & $\begin{array}{l}\text { Institutions could define: } \\
\text { - Standards e.g. on vehicle efficiency } \\
\text { - Obligations e.g. on the registration of chemical substances in } \\
\text { REACh } \\
\text { - Technology to be used e.g. imposing the use of the best } \\
\text { available technology }\end{array}$ \\
\hline & 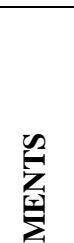 & $\begin{array}{l}\text { Voluntary } \\
\text { agreements }\end{array}$ & $\begin{array}{l}\text { Institutions and firms may agree on reducing pollution through: } \\
\text { - A specific target on emission/pollution reduction } \\
\text { - An implementation of a program } \\
\text { - A possible charge for non-complying agents }\end{array}$ \\
\hline & 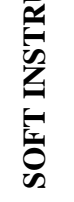 & $\begin{array}{l}\text { Information } \\
\text { based } \\
\text { instruments }\end{array}$ & $\begin{array}{l}\text { Improving consumers / suppliers / customers awareness through: } \\
\text { - Product certifications } \\
\text { - Labels }\end{array}$ \\
\hline & IPR & & $\begin{array}{l}\text { Enforcing / Creating a functioning Intellectual Property Right } \\
\text { protection mechanisms }\end{array}$ \\
\hline & Tax & dits & Allocating tax credits for innovative firms \\
\hline policy & $\mathrm{R} \& \mathrm{I}$ & ubsidies & Subsidising R\&D activities \\
\hline & Syst & ic instruments & $\begin{array}{ll}\text { - } & \text { Public R\&D labs } \\
\text { - } & \text { Technology Transfer instruments } \\
\text { - } & \text { Technology platforms }\end{array}$ \\
\hline
\end{tabular}

As EI are "special" innovations affected by a "double externality" (Rennings, 2000), the need for innovation policies to be specifically directed towards the development of EI emerges, as traditional innovation policies might not be enough to spur their development and adoption, given their peculiarities. Empirical analysis on the determinants of EI (e.g. Horbach et al., 2012; Rennings and Rexhauser, 2011) stress the central role of policy in inducing EI, and empirical analysis have confirmed regulation's pivotal role (Veugelers, 2012). This is something that has to be taken into account when eco-innovation policies are implemented. Moreover, not only the existence of innovation oriented environmental policy matters in stimulating EI, but also its stringency. In other words, it is the stringency of a regulation to affect the rate and direction of green technological change (Johnstone et al. 2010a; 2010b; 2012).

Some prescription on how innovation oriented environmental policies should look like have emerged from previous contributions. Del Rio and coauthors (2010) suggest some characteristics that policy instruments should have, which they label general features, or "framework conditions". For instance policy aimed at overcoming barriers to EI, for which a suggestion of simultaneously use and better integration of environmental and technology policies and of searching for a balancing 
between short-term protection and longer-term promotion of radical EI in order to avoid technological lock-ins is suggested. Lock-in in suboptimal technologies might be indeed a negative side effect of a policy, and this will favor the uptake of 'incremental' innovations, based on improvement of already existing technologies, rather than radical and systemic, e.g. the development of new technologies or products or services.

Furthermore, the complexity of EI suggests the need of policy instruments to fit each different phase of the process, from invention to diffusion, as effective policies should differ along the process (Jänicke \& Lindemann, 2010). Innovation policies to support R\&D might favor the invention phase, a command-and-control policy setting a technology standard can influence both the invention and the innovation phase as well as the dynamics of innovation diffusion. Information mechanisms such as eco-label can result to be central in the diffusion process of EI.

More precisely, market based instruments can influence the whole innovation cycle, as they alter the direction and rate of technological change. In this respect, a lead market policy can favor the early diffusion of EI and thus promote innovative investment. Some further prescription on how an innovation oriented environmental policy should be is that the ecological effect of EI should be the priority of the innovation. In other words "Environmental policy should not just promote any kind of environmental innovation but seek to maximize the ecological effectiveness of technology development" (Jänicke \& Lindemann, 2010:129). The authors differentiate between weak EI, e.g. incremental or radical innovation with low market penetration rates, and strong EI, e.g. incremental or radical EI that have high market penetration rates and thus an high environmental impact. All in all, greater environmental improvements are associated with radical EI with high penetration rates as "it is the replacement of coal-fired power plants by renewable energies rather than continuous incremental efficiency gains that will ensure the decoupling of environmental pressures from economic growth and the absolute reduction of environmental impacts" (Jänicke \& Lindemann, 2010:130). Coherently, policies should be focused on the uptake of strong EI, and in particular on radical ones, to maximize the environmental benefits.

To sum up, when the policy goal is to spur the uptake of EI, the adoption of a combination of instruments, policy mix, is not seen as a problem, but rather as a value added when environmental and innovation or technology-specific policies are combined. Such combination of policies can be facilitated by the development of governmental transition management schemes, in which the government facilitates and plans the transition to a greener economy by combining available instruments.

When this mix is optimal and covers the entire innovation life-cycle, literature uses the term "smart regulation" (Ekins and Venn 2006). The explanation to this (apparent) contradiction lies in the complementarity between environmental and innovation regulation. The first is designed to reduce negative, environmental externalities, while the second addresses positive externalities, mainly knowledge-related externalities, deriving from problem of appropriability of the benefits from innovation investments.

Neglecting the need to combine environmental and innovation policies can lead to "unintended and very undesirable outcomes" such as the "rebound effect" or technological lock-in (Biswanger, 2001; van den Bergh, 2013: 18). In the presence of a technology policy e.g. renewable energy 
subsidy and in the absence of an environmental regulation e.g. a carbon tax, the subsidy can increase the supply of electricity, reducing the prices for fuels, thus increasing their extraction, and increasing GHG emissions. In parallel, in the presence of environmental regulation without appropriate innovation policies, it can be more likely to observe technological lock-in as "Selection pressure will then favor currently cost-effective technologies which may lead to an early lock-in of these at the disadvantage of technological alternatives that are more desirable from a long-run perspective" (van den Bergh, 2013: 18). The presence of initial economic advantages for already existing technological trajectories built around dirty technologies can create lock-ins that, in the absence of a proper policy, may hamper the uptake of EI. In addition, the presence of inadequate policies can create such lock-ins. The case of internal combustion engines, described in Oltra and Saint Jean (2009) is an example of a dominant design of a dirty technology that has been continuously made more efficient through incremental innovations. This improved its environmental efficiency, but also led to technological inertia that prevented the development of radical innovations as alternative engine technologies e.g. electric or fuel cells vehicles. All in all, if adopting evolutionary lens some type of incremental innovations can even be detrimental when it reinforces existing inefficient (and possible more polluting) trajectories (Cecere et al., 2014).

In this respect, innovation policies designed to favor technological exploration activities and improve knowledge variety might be crucial in escaping technological lock-ins and fostering the evolution of green technologies. The implementation of sound and specific technology-push policies and increasing coordination between environmental and innovation policies certainly represent challenges to be addressed to increase the effectiveness of both.

Acknowledgments.

We would like to thank Klaus Rennings for his comments. We also acknowledge the financial contribution of the European Commission within the framework of the FP7 Collaborative Research Project WWWforEurope - Welfare, Wealth and Work for Europe, grant agreement n. 290647. 


\section{References}

Alt, J., Preston I, Sibieta L. (2010), The Political Economy of Tax Policy, in: Mirrlees J., Adam S., Besley T., Blundell R., Bond S., Chote R., Gammie M., Johnson P., Myles G., Poterba J. (eds), Dimensions of Tax Design: the Mirrlees Review, Oxford University Press, Oxford, 1204-1279.

Ambec, S., Cohen, M. A., Elgie, S., \& Lanoie, P. (2013). The Porter hypothesis at 20: can environmental regulation enhance innovation and competitiveness?. Review of Environmental Economics and Policy, 016.

Antonelli C., \& Crespi F. (2013), The Matthew Effect in R\&D Public Subsidies: the case of Italy, Technological Forecasting and Social Change, 80 pp. 1523-1534.

Arrow, K. (1962). Economic welfare and the allocation of resources for invention. In The rate and direction of inventive activity: Economic and social factors (pp. 609-626). Princeton University Press.

Beise, M. \& Rennings, K. (2005) Lead markets and regulation: a framework for analyzing the international diffusion of environmental innovations. Ecological Economics 52, 5-17.

Berman, E., \& Bui, L. T. M. (2001). Environmental Regulation and productivity: Evidence from oil refineries. The Review of Economics and Statistics, 83(3), 498-510.

Binswanger M (2001) Technological progress and sustainable development: what about the rebound effect? Ecological Economics, 36(1):119-132.

Bloom, N., Griffith, R., \& Van Reenen, J. (2002). Do R\&D tax credits work? Evidence from a panel of countries 1979-1997. Journal of Public Economics, 85(1), 1-31.

Böhringer, C., Löschel, A., Moslener, U., \& Rutherford, T. F. (2009). EU climate policy up to 2020 : An economic impact assessment. Energy Economics, 31, S295-S305.

Borghesi, S., Cainelli, G. \& Mazzanti, M. (2012) European Emission Trading Scheme and environmental innovation: an empirical analysis using CIS data for Italy. Giornale degli Economisti e Annali di Economia, 71(1), 71-97.

Borghesi, S., Crespi F., D’Amato A., Mazzanti, M., Silvestri, F. (2015), Carbon abatement, sector heterogeneity and policy responses: Evidence on induced eco innovations in the EU, Environmental Science and Policy, Forthcoming.

Brunnermeier, S. B., \& Levinson, A. (2004). Examining the Evidence on Environmental Regulations and Industry Location. The Journal of Environment \& Development, 13(1), 641.

Brunnermeier, S., \& Cohen, M. (2003). Determinants of environmental innovation in US manufacturing industries. Journal of Environmental Economics and Management, 45, 278293.

Calel, R., \& Dechezleprêtre, A. (2014). Environmental Policy and Directed Technological Change: Evidence from the European Carbon Market . Review of Economics and Statistics, forthcoming

Cave, L., \& Blomquist, G. (2008). Environmental policy in the European Union: Fostering the development of pollution havens? Ecological Economics, 65, 253-261. doi:10.1016/j.ecolecon.2007.12.018

Cecere, G., Corrocher, N., Gossart, C., \& Ozman, M. (2014). Lock-in and path dependence : an evolutionary approach to eco-innovations. Journal of Evolutionary Economics, 24, 10371065. 
Costantini, V., \& Mazzanti, M. (2012). On the green and innovative side of trade competitiveness ? The impact of environmental policies and innovation on EU exports. Research Policy, 41(1), 132-153. doi:10.1016/j.respol.2011.08.004

Costantini V., \& Crespi, F. (2008). Environmental regulation and the export dynamics of energy technologies, Ecological Economics, Vol. 66, No. 2-3, pp. 447-460.

Costantini V., \& Crespi F. (2013), Public policies for a sustainable energy sector: regulation, diversity and fostering of innovation, Journal of Evolutionary Economics, 23(2), 401-429.

Costantini V., Crespi F., Martini C., Pennacchio L., (2015), Demand-pull and technology-push public support for eco-innovation: The case of the biofuels sector, Research Policy, 44 (3), 577-595.

Crespi, F. and Quatraro, F. (2013). Systemic technology policies: Issues and instruments. Technological Forecasting and Social Change 80, 1447-1449.

Crespi, F. and Quatraro, F. (2015). The Economics of Knowledge, Innovation and Systemic Technology Policy. London and New York, Routledge.

David, P. A., \& Hall, B. H. (2000). Heart of darkness: modeling public-private funding interactions inside the R\&D black box. Research Policy, 29(9), 1165-1183.

David, P. A., Hall, B. H., \& Toole, A. A. (2000). Is public R\&D a complement or substitute for private R\&D? A review of the econometric evidence. Research Policy, 29(4), 497-529.

Dechezleprêtre, A., Glachant, M., \& Ménière, Y. (2008). The Clean Development Mechanism and the international diffusion of technologies: An empirical study. Energy Policy, 36(4), 12731283.

Del Río, P., Carrillo-Hermosilla, J., \& Könnölä, T. (2010). Policy Strategies to Promote EcoInnovation. Journal of Industrial Ecology, 14(4), 541-557.

De Serres, A., Murtin, F. \& Nicoletti, G. (2010) A framework for assessing green growth policies. OECD Economics department working paper series, n. 774.

De Serres, A., Llewellyn, J., \& Llewellyn, P. (2011). The Political Economy of Climate Change Mitigation Policies OECD Working paper 887.

De Vries, F. \& Medhi, N., (2008). Environmental regulation and international innovation in automotive emissions control technologies, in: Environmental Policy, Technological Innovation and Patents, Organisation for Economic Co-operation and Development, Paris.

Ekins, P. \& Venn, A., (2006). Assessing innovation dynamics induced by environmental policy. London: Policy Studies Institute.

EC. (2008). Proposal for a Directive of the European Parliament and Council amending Directive 2003/87/EC so as to improve and extend the greenhouse emission allowance trading system of the Community, COM (2008) 16 final, dated 23 January 2008

EC. (2010a) Europe 2020 Flagship Initiative Innovation Union, Communication from the

Commission to the European Parliament, the Council, the European Economic and Social Committee and the Committee of the Regions, $\operatorname{COM}(2010)$ 546, Brussels.

EC. (2010b). EUROPE 2020 A strategy for smart, sustainable and inclusive growth, Communication from the Commission to the European Parliament, the Council, the European Economic and Social Committee and the Committee of the Regions, COM(2010) 2020, Brussels

EC. (2012). Annual Growth Survey 2012 - Annex: Growth-Friendly Tax Policies in Member States and Better Tax Coordination in the EU, Communication from the Commission to the 
European Parliament, the Council, the European Economic and Social Committee and the Committee of the Regions, Vol.5/5 Annex IV, COM(2011) 815 final, Brussels.

EC. (2013). Tax reforms in EU Member States 2013 Tax policy challenges for economic growth and fiscal sustainability, European Economy 5/2013, Brussels.

EC. (2014). Energy Economic Developments in Europe, European Economy 1/2014, DirectorateGeneral for Economic and Financial Affairs, Brussels.

Edquist, C., Innovation Policy: A Systemic Approach, in: D. Archibugi and B.-Å. Lundvall (eds), The Globalizing Learning Economy, Oxford, Oxford University Press, (2001) 219-37.

EEA. (2005). Market-based instruments for environmental policy in Europe, Technical report No 8/2005, European Environment Agency, Copenhagen.

EEA. (2011). Environmental tax reform in Europe:opportunities for eco-innovation, Technical report No 17/2011, European Environment Agency,Copenhagen.

EEA. (2014). Resource-efficient green economy and EU policies. European Environment Agency Report n. 2, Copenhagen.

Ekins, P. (2010). Eco-innovation for environmental sustainability: concepts, progress and policies. International Economics and Economic Policy, 7, 267-290.

Flanagan, K., Uyarra, E. \& Laranja, M. (2011). Reconceptualising the 'policy mix' for innovation. Research Policy 40, 702-713.

Georghiou, L., Metcalfe, J.S., Equilibrium and evolutionary foundations of technology policy, STI

Review - Special Issue on New Rationale and Approaches in Technology and Innovation Policy, vol. 22. OECD, Paris (1998).

Ghisetti, C., Marzucchi, A., \& Montresor, S. (2015). The open eco-innovation mode. An empirical investigation of eleven European countries. Research Policy, 44(5), 1080-1093.

Ghisetti, C. and Quatraro, F. (2013). Beyond inducement in climate change: Does environmental performance spur environmental technologies? A regional analysis of cross-sectoral differences. Ecological Economics 96, 99-113.

Ghisetti, C., \& Rennings, K. (2014). Environmental innovations and profitability: How does it pay to be green? An empirical analysis on the German Innovation survey. Journal of Cleaner Production, 75, 106-117.

Gilli, M., Mazzanti, M., \& Nicolli, F. (2013). Sustainability and competitiveness in evolutionary perspectives: Environmental innovations, structural change and economic dynamics in the EU. The Journal of Socio-Economics 45, 204-215.

Gray, W. B., \& Shadbegian, R. J. (1998). Environmental Regulation, investment timing and technology choice. The Journal of Industrial Economics, XLVI(2), 235-256.

Greenstone, M. (2001). The impacts of environmental regulations on industrial activity: Evidence from the 1970 and 1977 clean air act amendments and the census of manufactures. NBER Working paper N. 8484.

Grossman, G. (1991), Promoting new industrial activities: A survey of recent arguments and evidence. OECD Econ. Stud, No. 14, (1991) 87-125.

Hall, B., \& Van Reenen, J. (2000). How effective are fiscal incentives for R\&D? A review of the evidence. Research Policy, 29(4), 449-469.

Hahn RW (1984) Market Power and Transferable Property Rights, Quarterly Journal of Economics, 99(4):753-765. 
Hintermann B (2011) Market Power, Permit Allocation and Efficiency in Emission Permit Markets, Environmental and Resource Economics, 49:327-349.

Horbach, J., Rammer, C., \& Rennings, K. (2012). Determinants of eco-innovations by type of environmental impact - The role of regulatory push / pull, technology push and market pull. Ecological Economics, 78, 112-122.

Huppes, G. (2011) Instruments for Effective Global Climate Policy: the Carbon Deposit system. Presentation at the Symposium "Making Climate Policy a Global reality: Instruments, Mechanisms, Consequences and Policy Process, University of Leiden, $16^{\text {th }}$ December 2011.

Jaffe, A., Newell, R., \& Stavins, R. (2002). Environmental policy and technological change. Environmental and resource economics, 22(1-2), 41-70.

Jaffe, A., \& Palmer, K. (1997). Environmental regulation and innovation: a panel data study. Review of Economics and Statistics. 79(4), 610-619.

Jänicke, M., \& Lindemann, S. (2010). Governing environmental innovations. Environmental Politics, 19(1), 127-141.

Johnstone, N., Haščič, I., \& Popp, D. (2010a). Renewable energy policies and technological innovation: evidence based on patent counts. Environmental and Resource Economics, 45, $133-155$.

Johnstone, N., Haščič, I., \& Kalamova, M. (2010b). Environmental Policy Design Characteristics and Technological Innovation. Evidence from patent data. OECD Environment Working paper n. 16.

Johnstone, N., Hašcic, I., Poirier, J., Hemar, M., \& Michel, C. (2012). Environmental policy stringency and technological innovation: evidence from survey data and patent counts. Applied Economics, 44(17), 2157-2170.

Kozluk, T., \& Zipperer, V. (2013). Environmental Policies and Productivity Growth OECD Economics Department Working Papers No. 1096, Paris.

Lanjouw, J., \& Mody, A. (1996). Innovation and the international diffusion of environmentally responsive technology. Research Policy, 25, 549-571.

Link, A. N. (1977). On the efficiency of federal R\&D spending: A public choice approach. Public Choice, 31(1), 129-133.

Martin, R., Muulus, M., De Preux L. B. \& Wagner, U. (2014a). Industry Compensation Under Relocation Risk: A Firm-level Analysis of the EU Emissions Trading Scheme. American Economic Review 104: 2482-2508.

Martin, R., Muulus, M., De Preux L. B. \& Wagner, U. (2014b). On the empirical content of carbon leakage criteria in the EU Emissions Trading Scheme. Ecological Economics 105, 78-88.

Mazzucato, M. (2013) The Entrepreneurial State: debunking private vs. public sector myths, London: Anthem Press.

Metcalfe J.S., (1995). Foundations of Technology Policy - Equilibrium and Evolutionary Perspectives. In: Stoneman, P., Dasgupta, P., Nelson, R. (eds.), Handbook in the Economics of Innovation, Blackwell.

Mohnen, P., \& Röller, L. H. (2005). Complementarities in innovation policy. European Economic Review, 49(6), 1431-1450.

Nelson, R. R. (1959). The economics of invention: A survey of the literature. The Journal of Business, 32(2), 101-127.

Nesta L., Vona F., Nicolli F. (2014). Environmental policies, competition and innovation in renewable energy, Journal of Environmental Economics and Management, 67(3):369-411. 
Morley, B. (2012). Empirical evidence on the effectiveness of environmental taxes. Applied Economics Letters, 19(18), 1817-1820.

OECD (2007). Science, Technology and Industry Scoreboard. Paris, OECD (2007). OECD (2010). Taxation, Innovation and the Environment, Organisation for Economic Co-operation and Development, Paris.

Oltra, V., \& Saint Jean, M. (2009). Sectoral systems of environmental innovation : An application to the French automotive industry. Technological Forecasting \& Social Change, 76(4), 567583.

Palmer, K., Oates, W. E., \& Portney, P. R. (1995). Tightening Environmental Standards: The Benefit-Cost or the No-Cost Paradigm? The Journal of Economic Perspectives, 9(4), 119 132.

Porter, M. E., \& Van der Linde, C. (1995). Toward a New Conception of the EnvironmentCompetitiveness Relationship. The Journal of Economic Perspectives, 9(4), 97-118.

Quitzow, R., Walz, R., Koehler, J. \& Rennings, K. (2014). The concept of "lead markets" revisited. Contribution to environmental innovation theory. Environmental innovation and societal transitions 10, 4-19.

Rammel, C., \& van der Bergh, J.C.J.M., (2003). Evolutionary policies for sustainable development: adaptive flexibility and risk minimising, Ecological Economics, Vol. 47, pp. 121-133.

Rennings, K. (2000). Redefining innovation - eco-innovation research and the contribution from ecological economics. Ecological economics, 32(2), 319-332.

Rennings, K. and Rexhäuser, S. (2011), Long-Term Impacts of Environmental Policy and EcoInnovative Activities of Firms, International Journal of Technology Policy and Management $11(3 / 4)$ 274-290.

Requate, T. (2005). Dynamic incentives by environmental policy instruments - a survey. Ecological Economics, 54, 175-195.

Schmidt, T.S., Schneider, M., Rogge, K.S., Schuetz, M.J.A., Hoffmann, V.O., 2012. The effects of climate policy on the rate and direction of innovation: a survey of the EU ETS and the electricity sector. Environ. Innov. Soc. Trans. 2, 23-48.

Stavins, Robert N., (2003). "Experience with market-based environmental policy instruments," Handbook of Environmental Economics, in: K. G. Mäler \& J. R. Vincent (ed.), Handbook of Environmental Economics, 1(1), pages 355-435.

Stiglitz, J. E., \& Wallsten, S. J. (2000). Public-private technology partnerships-promises and pitfalls. In P. Vaillancourt Rosenau (Ed.), Public-private policy partnerships (pp. 37-58). Cambridge, MA: The MIT Press.

Tollison, R.D. (1997). Rent seeking, Chapter 23 in Mueller, D C, Perspectives on Public Choice: A Handbook. Cambridge University Press, New York.

Van den Bergh, J. C. J. M (2013). Technological Forecasting \& Social Change Environmental and climate innovation: Limitations, policies and prices. Technological Forecasting \& Social Change, 80(1), 11-23.

Veugelers, R. (2012). Which policy instruments to induce clean innovating? Research Policy, 41(10), 1770-1778.

Vlachou, A. (2014). The European Union 's Emissions Trading System. Cambridge Journal of Economics, 38, 127-152.

Wood, P. J., \& Jotzo, F. (2011). Price floors for emissions trading. Energy Policy, 39(3), 17461753. 
Zetterberg, L. (2014). Benchmarking in the European Union Emissions Trading System: Abatement incentives. Energy Economics, 43, 218-224. 


\section{Appendix}

This Appendix provides empirical evidence on the inducement effects played by policies to support the discussion on the role of policies for environmental innovations outlined in the paper. It is worth noting that the estimated relations can only be considered as informative of the presence of conditional correlation between regulation and eco-innovation, and that only weak claims of causality can be done.

A country-sector level analysis based on Eurostat and OECD data sources is proposed, coherently with previous contributions that motivate the appropriateness of such a focus (e.g. Gilli et al. 2013). The aim of the appendix is to empirically test for the role of policies, measured in several alternative ways, in inducing the adoption of EI by firms.

The core data on environmental innovations adoption are taken from the Eurostat Community Innovation Survey for the year 2006-2008. As this survey introduced for the first time a section on EI adoption, the analysis is conducted on those countries that included such section in the survey and that made results available for consultation. Those are the following: Belgium, Bulgaria, Cyprus, Croatia, Czech Republic, Estonia, Finland, France, Germany, Hungary, Ireland, Italy, Latvia, Lithuania, Luxembourg, Malta, Netherland, Poland, Portugal, Romania, Slovakia and Sweden. As for the sectors included in the analysis, we focused on the following aggregates:

Table A1: Sectors included in the analysis

\begin{tabular}{|c|c|}
\hline NACE & \\
\hline $\mathrm{C} 10-\mathrm{C} 12$ & $\begin{array}{l}\text { Manufacture of food products } \\
\text { Manufacture of beverages } \\
\text { Manufacture of tobacco products }\end{array}$ \\
\hline C13-C15 & $\begin{array}{l}\text { Manufacture of textiles } \\
\text { Manufacture of wearing apparel } \\
\text { Manufacture of leather and related products }\end{array}$ \\
\hline C16-C18 & $\begin{array}{l}\text { Manufacture of wood and of products of wood and cork, except furniture; } \\
\text { manufacture of articles of straw and plaiting materials } \\
\text { Manufacture of paper and paper products } \\
\text { Printing and reproduction of recorded media }\end{array}$ \\
\hline C19-C22 & $\begin{array}{l}\text { Manufacture of coke and refined petroleum products } \\
\text { Manufacture of chemicals and chemical products } \\
\text { Manufacture of basic pharmaceutical products and pharmaceutical } \\
\text { Preparations }\end{array}$ \\
\hline
\end{tabular}




\begin{tabular}{|l|l|}
\hline C24-C25 & Manufacture of rubber and plastic products \\
& $\begin{array}{l}\text { Manufacture of basic metals } \\
\text { Manufacture of fabricated metal products, except machinery and } \\
\text { equipment }\end{array}$ \\
\hline C26-C30 & $\begin{array}{l}\text { Manufacture of computer, electronic and optical products } \\
\text { Manufacture of electrical equipment } \\
\text { Manufacture of machinery and equipment n.e.c. } \\
\text { Manufacture of motor vehicles, trailers and semi-trailers } \\
\text { Manufacture of other transport equipment } \\
\text { Manufacture of furniture } \\
\text { Other manufacturing } \\
\text { Repair and installation of machinery and equipment }\end{array}$ \\
\hline C31-C33 &
\end{tabular}

The baseline model we estimate is the one reported into Equation A1.

$$
E I_{(E C O C O 2-E C O S U B) i, j}=\alpha+\beta_{1} I S_{i, j}+\beta_{2} R D_{i, j}+\beta_{3} P_{O L I C Y}+\gamma_{i}+\gamma_{i}(\mathrm{~A} 1)
$$

Nine typologies of environmental innovations adopted constitute our dependent variables (EI). Previous literature highlighted the need to open the box of EI and to look into the heterogeneities that each typology of EI brings about (e.g. Ghisetti and Rennings, 2014). For this reason we estimate Equation A1 on nine different dependent variables, each of which represents the share of firms of the country-sector adopting a specific type of EI: reducing carbon dioxide emissions (EOCO2), energy use per unit of output (ECOEN) or after sales use (ECOENU), material use (ECOMAT), soil, water, noise, or air pollution per output (ECOPOL) or after sales use (ECOPOS), improving recycling per output (ECOREC) or after sales use (ECOREA) and replacing materials with less polluting or hazardous substitutes (ECOREC). Estimations are carried out though Ordinary Least Squares estimator with robust standard errors to cope with heteroscedasticity problems. As EI adoption has been surveyed in the CIS 2006-2008, we are only able to run a cross-sectional analysis in which dependent and explanatory variables refer either to the period 20062008 (EI variables, RD, REG, FUT_REG, GRANTS) or to 2008 (POL_index, 1Co2_va).

As for the explanatory variables, we drew on already established literature to derive a set of core control variables to be included (e.g. Ghisetti et al. 2015; Horbach et al 2012). Given the low number of observations, we had not enough degrees of freedom to include additional variables. In particular, we chose to control for the role of external R\&D activities (RD) and country dummies to capture structural country heterogeneities and we included our core policy variable, which has been constructed in alternative ways. As policy does incorporate an induction effect on internal $R \& D$, we have opted to include the external $R \& D$ variable to avoid potential biases. Whereas our sample equals 134 observations in the case of a policy variable constructed from CIS data, it falls to 68 and 71 when exploiting alternative policy measures, as data are not available for all the countries of the first dataset, more precisely Eastern EU countries are excluded. 
Table A2 reports the variables short description together with their descriptive statistics, while Table A3 outlines the pairwise correlations among them.

Table A2: Variables descriptive statistics

\begin{tabular}{|c|c|c|c|c|c|c|}
\hline Variables & Description & $\mathbf{N}$ & mean & Sd & $\min$ & $\max$ \\
\hline & & 134 & 0.217 & 0.0993 & 0.0238 & 0.491 \\
\hline ECOCO2 & Share of firms adopting EI aimed at reducing carbon dioxide emissions & & & & & \\
\hline ECOEN & $\begin{array}{l}\text { Share of firms adopting EI aimed at reducing energy use per unit of } \\
\text { output }\end{array}$ & 134 & 0.337 & 0.131 & 0.0319 & 0.620 \\
\hline & & 134 & 0.272 & 0.115 & 0.0347 & 0.519 \\
\hline ECOENU & Share of firms adopting EI aimed at reducing energy use after sales use & & & & & \\
\hline ECOMAT & $\begin{array}{l}\text { Share of firms adopting EI aimed at reducing material use per unit of } \\
\text { output }\end{array}$ & 134 & 0.331 & 0.122 & 0 & 0.641 \\
\hline ECOPOL & $\begin{array}{l}\text { Share of firms adopting EI aimed at reducing soil, water, noise, or air } \\
\text { pollution }\end{array}$ & 134 & 0.303 & 0.129 & 0 & 0.629 \\
\hline ECOPOS & $\begin{array}{l}\text { Share of firms adopting EI aimed at reducing air, water, soil or noise } \\
\text { pollution after sales use }\end{array}$ & 134 & 0.241 & 0.115 & 0 & 0.541 \\
\hline ECOREA & $\begin{array}{l}\text { Share of firms adopting EI aimed at improving recycling of product } \\
\text { after use }\end{array}$ & 134 & 0.234 & 0.119 & 0 & 0.493 \\
\hline & & 134 & 0.346 & 0.168 & 0 & 0.752 \\
\hline ECOREC & ng EI aimed at recycling waste, w & & & & & \\
\hline ECOSUB & $\begin{array}{l}\text { Share of firms adopting EI aimed at replacing materials with less } \\
\text { polluting or hazardous substitutes }\end{array}$ & 134 & 0.292 & 0.126 & 0 & 0.765 \\
\hline UT $R$ & Moti & 134 & 0.212 & 0.108 & 0 & 0.575 \\
\hline GRANTS & $\begin{array}{l}\text { Motivation of availability of grants or subsidies as a driver of the } \\
\text { innovation adopted }\end{array}$ & 134 & 0.0742 & 0.0483 & 0 & 0.266 \\
\hline REG & $\begin{array}{l}\text { Motivation of existing regulation or taxes on pollution as a driver of the } \\
\text { innovation adopted }\end{array}$ & 134 & 0.284 & 0.142 & 0 & 0.708 \\
\hline POL index & $\begin{array}{l}\text { Policy index constructed as the sum of existing environmental policies } \\
\text { as in the OECD Environmental Policy Indicators dataset }\end{array}$ & 71 & 0.608 & 0.591 & 0 & 2.333 \\
\hline RD & Shar & 134 & 0.225 & 0.127 & 0 & 0.657 \\
\hline $\mathrm{CO} 2$ & acter & 68 & 0.757 & 2.169 & 0.0116 & 15.82 \\
\hline
\end{tabular}


Table A3: Variables pairwise correlation matrix

\begin{tabular}{|c|c|c|c|c|c|c|c|c|c|c|c|c|c|c|c|c|}
\hline & & 1 & 2 & 3 & 4 & 5 & 6 & 7 & 8 & 9 & 10 & 11 & 12 & 13 & 14 & $\overline{15}$ \\
\hline 1 & $\mathrm{ECOCO} 2$ & 1 & & & & & & & & & & & & & & \\
\hline 2 & ECOEN & $0.7146^{*}$ & 1 & & & & & & & & & & & & & \\
\hline 3 & ECOENU & $0.6407 *$ & $0.7356^{*}$ & 1 & & & & & & & & & & & & \\
\hline 4 & ECOMAT & $0.6225^{*}$ & $0.7611^{*}$ & $0.6511^{*}$ & 1 & & & & & & & & & & & \\
\hline 5 & ECOPOL & $0.6410^{*}$ & $0.7333^{*}$ & $0.6624 *$ & $0.6518^{*}$ & 1 & & & & & & & & & & \\
\hline 6 & ECOPOS & $0.4972 *$ & $0.5972 *$ & $0.7785^{*}$ & $0.5867 *$ & $0.8287^{*}$ & 1 & & & & & & & & & \\
\hline 7 & ECOREA & $0.5826^{*}$ & $0.6184^{*}$ & $0.7526^{*}$ & $0.6126^{*}$ & $0.7602 *$ & $0.7966^{*}$ & 1 & & & & & & & & \\
\hline 8 & ECOREC & $0.6294 *$ & $0.6426^{*}$ & $0.6501 *$ & $0.6136^{*}$ & $0.7714^{*}$ & $0.6887^{*}$ & $0.8698^{*}$ & 1 & & & & & & & \\
\hline 9 & ECOSUB & $0.5100^{*}$ & $0.5329^{*}$ & $0.4683^{*}$ & $0.6571^{*}$ & $0.6614^{*}$ & $0.5188^{*}$ & $0.5878^{*}$ & $0.5772 *$ & 1 & & & & & & \\
\hline 10 & FUT REG & $0.2592 *$ & $0.5126^{*}$ & $0.3617^{*}$ & $0.5515^{*}$ & $0.4351 *$ & $0.4222 *$ & $0.4167 *$ & $0.3172 *$ & $0.4669^{*}$ & 1 & & & & & \\
\hline 11 & GRANTS & $0.3404 *$ & $0.3116^{*}$ & $0.3933 *$ & $0.3803^{*}$ & $0.4076^{*}$ & $0.4653^{*}$ & $0.4921 *$ & $0.3812^{*}$ & $0.2955^{*}$ & $0.4475^{*}$ & 1 & & & & \\
\hline 12 & REG & $0.1836^{*}$ & $0.4566^{*}$ & $0.3463 *$ & $0.4575^{*}$ & $0.4336^{*}$ & $0.4421^{*}$ & $0.4140^{*}$ & $0.3256^{*}$ & $0.4086^{*}$ & $0.8712 *$ & $0.4204 *$ & 1 & & & \\
\hline 13 & $\mathrm{RD}$ & $0.2061 *$ & $0.2653^{*}$ & $0.2729 *$ & $0.2964 *$ & $0.2294^{*}$ & 0.170 & $0.2661 *$ & $0.3504 *$ & $0.3043^{*}$ & $0.1744^{*}$ & 0.0948 & -0.0236 & 1 & & \\
\hline 14 & co2 va & 0.163 & 0.228 & 0.211 & 0.215 & 0.249 & $0.2689 *$ & 0.238 & 0.210 & 0.153 & $0.3381^{*}$ & 0.00450 & 0.168 & -0.0258 & 1 & \\
\hline 15 & POL index & 0.129 & 0.0480 & 0.00470 & -0.0347 & 0.186 & 0.0782 & 0.0232 & 0.0463 & 0.0781 & $0.2904 *$ & 0.242 & 0.216 & 0.0154 & $0.2840^{*}$ & 1 \\
\hline
\end{tabular}


At first, we built a policy variable able to capture a broad measure of environmental regulatory stringency. Drawing on previous literature (Costantini and Crespi, 2008) it has been built as the logarithm of the ratio between carbon dioxide emissions and value added (1CO2_va). The results of this first model are reported in table A4 and support is found for the inducement effect played by environmental regulation stringency on the share of adoption of EI, though with some exceptions in which regulatory stringency does not display any significant effect.

Table A4: Results on environmental policy built as an environmental policy stringency variable

\begin{tabular}{|c|c|c|c|c|c|c|c|c|c|}
\hline & $\begin{array}{c}(1) \\
\text { ECOCO2 }\end{array}$ & $\begin{array}{c}(2) \\
\text { ECOEN }\end{array}$ & $\begin{array}{c}(3) \\
\text { ECOENU }\end{array}$ & $\begin{array}{c}\text { (4) } \\
\text { ECOMAT }\end{array}$ & $\begin{array}{c}(5) \\
\text { ECOPOL }\end{array}$ & $\begin{array}{c}(6) \\
\text { ECOPOS }\end{array}$ & $\begin{array}{c}(7) \\
\text { ECOREA }\end{array}$ & $\begin{array}{c}\text { (8) } \\
\text { ECOREC }\end{array}$ & $\begin{array}{c}(9) \\
\text { ECOSUB }\end{array}$ \\
\hline RD & $\begin{array}{c}0.1757 \\
(0.1110)\end{array}$ & $\begin{array}{c}0.3655^{* * * *} \\
(0.1191)\end{array}$ & $\begin{array}{c}0.5001^{* * * *} \\
(0.1119)\end{array}$ & $\begin{array}{c}0.3613^{\text {**** }} \\
(0.1166)\end{array}$ & $\begin{array}{c}0.1046 \\
(0.0962)\end{array}$ & $\begin{array}{c}0.3350^{* * * *} \\
(0.1048)\end{array}$ & $\begin{array}{c}0.2688^{* * * * *} \\
(0.0993)\end{array}$ & $\begin{array}{l}0.2210^{* *} \\
(0.0990)\end{array}$ & $\begin{array}{c}0.3388^{* * * * *} \\
(0.1104)\end{array}$ \\
\hline lco2_va & $\begin{array}{c}0.0092 \\
(0.0061)\end{array}$ & $\begin{array}{c}0.0165^{* * * *} \\
(0.0053)\end{array}$ & $\begin{array}{l}-0.0021 \\
(0.0052)\end{array}$ & $\begin{array}{l}0.0089^{*} \\
(0.0053)\end{array}$ & $\begin{array}{c}0.0219^{* * * *} \\
(0.0054)\end{array}$ & $\begin{array}{c}0.0084^{*} \\
(0.0044)\end{array}$ & $\begin{array}{c}0.0050 \\
(0.0048)\end{array}$ & $\begin{array}{c}0.0180^{* * * *} \\
(0.0055)\end{array}$ & $\begin{array}{c}0.0013 \\
(0.0049)\end{array}$ \\
\hline Constant & $\begin{array}{c}0.3257^{* * *} \\
(0.0313)\end{array}$ & $\begin{array}{c}0.3334^{* * * *} \\
(0.0480)\end{array}$ & $\begin{array}{c}0.2801^{* * *} \\
(0.0408)\end{array}$ & $\begin{array}{c}0.3057^{* * * *} \\
(0.0473)\end{array}$ & $\begin{array}{c}0.3365^{* * * *} \\
(0.0285) \\
\end{array}$ & $\begin{array}{c}0.2154^{* * * *} \\
(0.0526)\end{array}$ & $\begin{array}{c}0.3606^{* * * *} \\
(0.0278)\end{array}$ & $\begin{array}{c}0.5800^{\text {**** }} \\
(0.0431)\end{array}$ & $\begin{array}{c}0.3306^{* * * *} \\
(0.0390)\end{array}$ \\
\hline$N$ & 68 & 68 & 68 & 68 & 68 & 68 & 68 & 68 & 68 \\
\hline$R^{2}$ & 0.6640 & 0.7180 & 0.6707 & 0.6621 & 0.7106 & 0.6703 & 0.7701 & 0.8441 & 0.6332 \\
\hline $\begin{array}{c}\text { Country } \\
D\end{array}$ & yes & yes & yes & yes & yes & yes & yes & yes & yes \\
\hline
\end{tabular}

Standard errors in parentheses

${ }^{*} p<0.10,{ }^{* *} p<0.05,{ }^{* * * *} p<0.01$

As an alternative to this broad measure of policy intervention, we conducted further estimations in which the policy variable has been replaced with alternative measures.

In the second round of estimations, the policy-related variable has been extracted from the CIS 2006-2008 survey. It refers to the motivations that drove firms to adopt EI. In particular, we selected among the available options the adoption of EI consequently to existing regulations or taxes on pollution (REG), to expected forthcoming regulations (FUT_REG) or to the availability of subsidies and grants (GRANTS). In the second model, we thus jointly included REG, FUT_REG and GRANTS to test for the role of these motivations in driving the rate of EI's adoption. As it emerges from Table A4 GRANTS do actually drive EI's adoption choices in the case of ECOMAT, ECOPOL, ECOPOS and ECOREC, while the expectations over an upcoming environmental regulation, is a significant driver of EI in most of the cases, with the only exceptions of ECOENU, ECOPOL and ECOREC. Surprisingly instead the role of existing regulation and taxes of pollution is found to play only a rather marginal role, as it determines EI only in the case of recycling related innovations (ECOREA and ECOREC).

Table A5: Results on environmental policy built from CIS data

\begin{tabular}{|c|c|c|c|c|c|c|c|c|c|}
\hline & (1) & (2) & (3) & (4) & (5) & (6) & (7) & (8) & (9) \\
\hline & $\mathrm{ECOCO} 2$ & ECOEN & ECOENU & ECOMAT & ECOPOL & ECOPOS & ECOREA & ECOREC & ECOSUB \\
\hline RD & $\begin{array}{c}-0.0060 \\
(0.0648)\end{array}$ & $\begin{array}{c}0.1448 \\
(0.0901)\end{array}$ & $\begin{array}{l}0.2111^{* *} \\
(0.0923)\end{array}$ & $\begin{array}{c}0.0933 \\
(0.1077)\end{array}$ & $\begin{array}{c}0.0308 \\
(0.0779)\end{array}$ & $\begin{array}{c}0.1451^{*} \\
(0.0775)\end{array}$ & $\begin{array}{c}0.0365 \\
(0.0754)\end{array}$ & $\begin{array}{c}0.1041 \\
(0.0871)\end{array}$ & $\begin{array}{c}0.1675 \\
(0.1265)\end{array}$ \\
\hline REG & $\begin{array}{c}0.1444 \\
(0.1221)\end{array}$ & $\begin{array}{c}0.0655 \\
(0.1399)\end{array}$ & $\begin{array}{l}-0.0593 \\
(0.1426)\end{array}$ & $\begin{array}{l}-0.1211 \\
(0.1618)\end{array}$ & $\begin{array}{l}-0.0897 \\
(0.2842)\end{array}$ & $\begin{array}{c}-0.1687 \\
(0.1898)\end{array}$ & $\begin{array}{c}0.2557^{*} \\
(0.1362)\end{array}$ & $\begin{array}{l}0.3191^{* * *} \\
(0.1457)\end{array}$ & $\begin{array}{c}0.0430 \\
(0.2860)\end{array}$ \\
\hline FUT_REG & $\begin{array}{l}0.3146^{* *} \\
(0.1472)\end{array}$ & $\begin{array}{c}0.3456^{*} \\
(0.1789)\end{array}$ & $\begin{array}{c}0.2757 \\
(0.1664)\end{array}$ & $\begin{array}{c}0.5621^{* * * *} \\
(0.1939)\end{array}$ & $\begin{array}{c}0.3148 \\
(0.2353)\end{array}$ & $\begin{array}{l}0.3628^{* * *} \\
(0.1652)\end{array}$ & $\begin{array}{l}0.2629^{* *} \\
(0.1287)\end{array}$ & $\begin{array}{c}0.1467 \\
(0.1884)\end{array}$ & $\begin{array}{l}0.5672^{* * *} \\
(0.2546)\end{array}$ \\
\hline GRANTS & $\begin{array}{c}-0.0301 \\
(0.1766)\end{array}$ & $\begin{array}{c}0.2980 \\
(0.1845)\end{array}$ & $\begin{array}{c}0.2890 \\
(0.2004)\end{array}$ & $\begin{array}{l}0.5415^{* *} \\
(0.2173)\end{array}$ & $\begin{array}{l}0.8452^{* * *} \\
(0.3300)\end{array}$ & $\begin{array}{c}0.7365^{* * * *} \\
(0.2737)\end{array}$ & $\begin{array}{c}0.3255 \\
(0.2427)\end{array}$ & $\begin{array}{l}0.5352^{\text {** }} \\
(0.2056)\end{array}$ & $\begin{array}{c}0.2187 \\
(0.4402)\end{array}$ \\
\hline Constant & 0.1747 & 0.1581 & 0.1865 & 0.1126 & $\begin{array}{l}-0.0211 \\
26\end{array}$ & 0.0625 & 0.0161 & -0.0333 & -0.0313 \\
\hline
\end{tabular}




\begin{tabular}{lccccccccc} 
& $(0.1261)$ & $(0.1395)$ & $(0.1170)$ & $(0.0905)$ & $(0.0244)$ & $(0.0516)$ & $(0.0204)$ & $(0.0309)$ & $(0.0316)$ \\
\hline$N$ & 134 & 134 & 134 & 134 & 134 & 134 & 133 & 134 & 134 \\
$R^{2}$ & 0.7703 & 0.7905 & 0.7360 & 0.7325 & 0.7456 & 0.7438 & 0.8630 & 0.8744 & 0.6109 \\
Country D & yes & yes & yes & yes & yes & Yes & yes & yes & yes \\
\hline
\end{tabular}

Standard errors in parentheses

${ }^{*} p<0.10,{ }^{* *} p<0.05,{ }^{* * *} p<0.01$

Table A6: Results on composite policy index

\begin{tabular}{|c|c|c|c|c|c|c|c|c|c|}
\hline & $\begin{array}{c}(1) \\
\text { ECOCO2 }\end{array}$ & $\begin{array}{c}(2) \\
\text { ECOEN }\end{array}$ & $\begin{array}{c}(3) \\
\text { ECOENU }\end{array}$ & $\begin{array}{c}\text { (4) } \\
\text { ECOMAT }\end{array}$ & $\begin{array}{c}(5) \\
\text { ECOPOL }\end{array}$ & $\begin{array}{c}(6) \\
\text { ECOPOS }\end{array}$ & $\begin{array}{c}(7) \\
\text { ECOREA }\end{array}$ & $\begin{array}{c}(8) \\
\text { ECOREC }\end{array}$ & $\begin{array}{c}(9) \\
\text { ECOSUB }\end{array}$ \\
\hline RD & $\begin{array}{c}0.0806 \\
(0.0972)\end{array}$ & $\begin{array}{l}0.2622^{* *} \\
(0.1035)\end{array}$ & 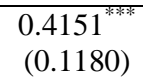 & $\begin{array}{l}0.3051^{\text {** }} \\
(0.1199)\end{array}$ & $\begin{array}{c}0.1617 \\
(0.1025)\end{array}$ & $\begin{array}{c}0.3598^{* * * *} \\
(0.1072)\end{array}$ & $\begin{array}{c}0.3083^{* * * *} \\
(0.0858)\end{array}$ & $\begin{array}{c}0.2766^{* * * *} \\
(0.1002)\end{array}$ & $\begin{array}{c}0.4244^{* * * * 1} \\
(0.1381)\end{array}$ \\
\hline POL_index & $\begin{array}{c}0.0280^{*} \\
(0.0146)\end{array}$ & $\begin{array}{c}0.0369^{* * * *} \\
(0.0136)\end{array}$ & $\begin{array}{c}0.0169 \\
(0.0151)\end{array}$ & $\begin{array}{l}0.0325^{* *} \\
(0.0149)\end{array}$ & $\begin{array}{c}0.0702^{* * * *} \\
(0.0136)\end{array}$ & $\begin{array}{l}0.0302^{* *} \\
(0.0134)\end{array}$ & $\begin{array}{c}0.0104 \\
(0.0119)\end{array}$ & $\begin{array}{c}0.0500^{* * *} \\
(0.0115)\end{array}$ & $\begin{array}{c}0.0281^{*} \\
(0.0149)\end{array}$ \\
\hline Constant & $\begin{array}{c}0.3204^{* * * *} \\
(0.0528)\end{array}$ & $\begin{array}{c}0.2474^{* * * *} \\
(0.0389)\end{array}$ & $\begin{array}{l}0.1011^{\text {*** }} \\
(0.0491)\end{array}$ & $\begin{array}{c}0.2860^{* * * *} \\
(0.0811)\end{array}$ & $\begin{array}{c}0.3175^{* * *} \\
(0.0782)\end{array}$ & $\begin{array}{l}0.1618^{* * *} \\
(0.0641)\end{array}$ & $\begin{array}{c}0.2057^{* * *} \\
(0.0538)\end{array}$ & $\begin{array}{c}0.4861^{* * * *} \\
(0.0514)\end{array}$ & $\begin{array}{c}0.2048 \\
(0.1276)\end{array}$ \\
\hline$N$ & 71 & 71 & 71 & 71 & 71 & 71 & 71 & 71 & 71 \\
\hline & 0.6616 & 0.7010 & 0.6461 & 0.6489 & 0.7082 & 0.6421 & 0.7515 & 0.8399 & 0.5615 \\
\hline Country D & yes & yes & yes & yes & yes & Yes & yes & yes & yes \\
\hline
\end{tabular}

Standard errors in parentheses

${ }^{*} p<0.10,{ }^{* * *} p<0.05,{ }^{* * * *} p<0.01$

We then exploited the OECD database on instruments used for environmental policy and natural resources management that collects information on environmentally related taxes, fees and charges, tradable permit systems, deposit refund systems, environmentally motivated subsidies and voluntary approaches used in environmental policy. In the third round of estimations, we built the policy variable as an index that counts the number of instruments in place for each country-sector (POL_index) among environmentally related taxes, fees and charges, tradable permit systems, voluntary approaches, deposit refund schemes and subsidies. This variable emerges to be as expected a significant driver for most the typologies of EI, with the only exception of ECOENU and ECOREA.

Overall, we can conclude that, coherently with the literature scrutinized in the paper, policies are found to play a crucial role in supporting or even spurring the adoption of environmental innovations. We then differentiated among i) typologies of policy instruments and ii) typologies of innovations. We found support that actually the inducement effects depend on the type of instrument under scrutiny: this is coherent with the qualitative overview of available policy instruments provided in the paper. We also found empirical support to the argument linking inducement effects of a policy and the specific type of EI one may be willing to spur, as heterogeneous EI differently react to the array of policy instruments scrutinized. Given the cross-sectoral nature of the available dataset and the consequently limited empirical setting, it is needed to acknowledge as the main limitation of this exercise the fact that we can interpret the relation between EI and policy as a (significant) correlation, rather than as a proper causality effect of policy on EI. 